\title{
NEW RECORDS OF ECTOPARASITES FROM Patagioenas picazuro (Temminck 1813) IN MINAS GERAIS, BRAZIL
}

(Novos registros de ectoparasitas de Patagioenas picazuro (Temminck 1813) em Minas Gerais, Brasil)

Bárbara Cristina Félix Nogueira ${ }^{1}$, José Eduardo Garcia Campos², Liara Azevedo Cassianoํㅜ, Artur Kanadani Campos ${ }^{1}$, Rômulo Ribon ${ }^{2}$

1Departamento de Medicina Veterinária, Universidade Federal de Viçosa, Viçosa, Minas Gerais, Brasil. 2Departamento de Biologia Animal, Universidade Federal de Viçosa, Viçosa, Minas Gerais, Brasil.

*Corresponding author: barbara.felix@ufv.br

ABSTRACT: Patagioneas picazuro (Temminck 1813) are Columbidae considered pests due to damages they cause to grain crops and problems related to overpopulation. They also may act as hosts of parasites that can generate public health problems. The aim of this study was to report the ectoparasites on P. picazuro in Viçosa, Minas Gerais, Brazil, as well as to identify the presence of pathogens that may use these arthropods as vectors. The collected arthropods were morphologically identified as Ornithoctona erythrocephala (Leach 1817) (Diptera: Hippoboscidae) and Columbicola passerinae (Wilson 1941) (Phthiraptera: Philopteridae). Ectoparasite DNA was extracted and molecularly processed by Polymerase Chain Reaction (PCR). Samples were screened for the presence of Ehrlichia spp., Anaplasma spp., and Rickettsia spp, but the results were negative for the pathogens tested. Further studies need to be performed in order to identify the role these ectoparasites have on the transmission of pathogens, and whether they act as biological or mechanical vectors. This is the first report of Ornithoctona erythrocephala in Minas Gerais and the first record of parasitism by Columbicola passerinae in Patagioneas picazuro.

Key words: Birds; Columbiformes; Diptera; Hippoboscidae; Philopteridae; Phthiraptera.

RESUMO: Patagioneas picazuro (Temminck 1813) são Columbidae consideradas pragas devido a danos causados às lavouras de grãos e problemas relacionados à superpopulação. Eles também podem atuar como hospedeiros de parasitas que podem gerar problemas de saúde pública. O objetivo deste estudo foi relatar os ectoparasitos em P. picazuro em Viçosa, Minas Gerais, Brasil, bem como identificar a presença de patógenos que podem usar esses artrópodes como vetores. Os artrópodes coletados foram identificados morfologicamente como Ornithoctona erythrocephala (Leach 1817) (Diptera: Hippoboscidae) e Columbicola passerinae (Wilson 1941) (Phthiraptera: 
Philopteridae). O DNA dos ectoparasitas foi extraído e processado molecularmente por Reação em Cadeia da Polimerase (PCR). As amostras foram rastreadas quanto à presença de Ehrlichia spp., Anaplasma spp. e Rickettsia spp., porém os resultados foram negativos para os patógenos testados. Mais estudos precisam ser realizados para identificar o papel desses ectoparasitas na transmissão de patógenos e se eles atuam como vetores biológicos ou mecânicos. Este é o primeiro relato de Ornithoctona erythrocephala em Minas Gerais e o primeiro registro de parasitismo por Columbicola passerinae em Patagioneas picazuro.

Palavras-chave: Pássaros; Columbiformes; Diptera; Hippoboscidae; Philopteridae; Phthiraptera.

\section{INTRODUCTION}

The Picazuro Pigeon Patagioenas picazuro (Temminck 1813) (Columbiformes: Columbidae) has a wide geographic distribution in South America, being found across most of Brazil, Argentina, Bolívia and Paraguay in both urban and rural environments (WikiAves, 2008). Some Columbidae species, including P. picazuro, are considered pests due to damages they cause to grain crops (Ranvaud and Bucher, 2006) and problems related to overpopulation (Lefeberve, 1985). In addition, they may act as hosts of parasites that can generate public health problems (Adriano et al., 2000; Gonzalez et al., 2004).

Among the Diptera that parasitize birds, the family Hippoboscidae presents 21 genera with 200 species of flies by far described; within them, 30 species, distributed in 10 genera have been recorded in Brazil (Maa, 1989; Lutz et al., 1915; Bequaert, 1957; Graciolli and Carvalho, 2003). These insects are known as louse-flies or keds and feed on the blood of their vertebrate hosts. They are morphologically characterized by a dorsoventrally wide and flattened body, small head narrowly fixed to the prothorax, and sturdy legs with claws that help the fixation on their hosts (Bequaert, 1942; Maa and Peterson, 1987). These flies parasitize mammals and birds, being the latter responsible for their wide dissemination, due to the migratory habits exhibited by some of them (Lutz et al., 1915; Guimarães, 1945; Bequaert, 1954; Baker, 1967; McClure, 1984; Maa and Peterson, 1987).

Species of Hippoboscidae may present substantial importance in terms of dissemination of diseases, as they act as vectors of pathogens of public health and veterinary concern, such as protozoa (i.e., Trypanossoma spp.) and bacteria (i.e., Anaplasma spp.) (Baker, 1967; Foley et al., 2016). In addition, they are able to carry arthropods of the order Phthiraptera on their body, establishing a phoretic relationship 
with lice (Keirans, 1975) frequently found on birds (Price et al., 2003) and on some mammals (Emerson and Price, 1981).

Chewing lice are small, wingless, and dorsoventrally flattened with chewing nipples, and can negatively affect their hosts, since they feed on feathers, skin scales and secretions often from birds and some mammals (Seegar et al., 1976; Cohen et al., 1991). These lice can also act as hosts and vectors for other parasites, such as the nematode Sarconema eurycerca (Price et al., 2003).

The relationship between birds and their ectoparasites is subject to many studies due to the capacity that these arthropods have to act as vectors of pathogens (Pavlovsky and Tokarevich, 1966; Hildebrandt et al., 2010). Therefore, the aim of this study was to report the first record of Ornithoctona erythrocephala (Leach 1817) and Columbicola passerinae (Wilson 1941) on P. picazuro in the state of Minas Gerais, Brazil, as well as to identify the presence of pathogens that may use these arthropods as vectors.

\section{MATERIAL AND METHODS}

The specimens of $P$. picazuro were collected in August and September 2016 in the Campo Experimental Diogo Alves de Melo at the campus of the Universidade Federal de Viçosa (UFV), Viçosa, Minas Gerais, Brazil (2046'3.74"S, 4252'10.67"W).

The use of the animals for the present study was authorized by the Biodiversity Information and Authorization System (SISBIO) of the Brazilian Institute of Environment and Renewable Natural Resources (IBAMA) under the license number: 13066-2. This authorization was requested for histological studies on this species, and the data on ectoparasites herein presented is an extension of that research.

The pigeons were collected by sitting and waiting for birds to be shot. A $4.5 \mathrm{~mm}$ air-pressure shotgun was used to shot the birds. Although this equipment has a very low success rate at killing birds as large as pigeons and parakeet at a dozen meters, we were forced to use it due to restrictions imposed by the Federal Law 10.826/2003. Birds were inspected for the presence of ectoparasites, which were collected, stored in plastic vials containing $70 \%$ alcohol, and sent to the Laboratory of Parasitology and Parasitic Diseases of the Veterinary Medicine Department/ Universidade Federal de Viçosa for morphological identification and molecular processing. After inspection for ectoparasites, the slaughtered birds were sent to the bird collection of the Laboratory of Ornithology of the Animal Biology Department/ Universidade Federal de Viçosa to be submitted to the taxidermy process. The birds were registered in the ornithological collection of the 
Museum of Zoology João Moojen/ Universidade Federal de Viçosa, under numeric codes 1977, 1978, 2043, 2044, 2045 and 2046.

The ectoparasites were identified using a stereoscopic microscope and dichotomous keys for flies (Lutz et al., 1915; Maa, 1969; Graciolli and Carvalho, 2003) and lice (Clayton and Price, 1999).

For the molecular processing, DNA of the ectoparasites was extracted according to Ramos et al. (2015). Afterward, the material was screened through Polymerase Chain Reaction (PCR) for the presence of arthropod borne pathogens (Table 1). The ectoparasites have an identification number according to the bird in which they were collected, the DNA was stored in the ultra-freezer at $-80^{\circ} \mathrm{C}$ in the Laboratory of Parasitology and Parasitic Diseases of the Veterinary Medicine Department/ Universidade Federal de Viçosa.

Amplification was done using Taq Pol Master Mix Green 2X according to manufacturer's instructions, including $400 \mathrm{nmol}$ of each primer, $5 \mu \mathrm{L}$ of DNA sample, and nuclease free water until complete $25 \mu \mathrm{L}$ volume.

Table 1. Primers used for molecular analysis.

\begin{tabular}{|c|c|c|c|c|c|}
\hline Pathogen & Gene & $\begin{array}{l}\text { Amplicon } \\
\text { size (bp) }\end{array}$ & $\begin{array}{c}\text { DNA } \\
\text { amplification }\end{array}$ & Primer sequence & Reference \\
\hline Rickettsia spp. & gt|A & $300-380$ & $\begin{array}{c}35 \text { cycles of } \\
\text { denaturation } \\
\left(20 \mathrm{~s} \text { at } 95^{\circ} \mathrm{C}\right) \text {, } \\
\text { annealing } \\
\left(30 \mathrm{~s} \text { at } 48^{\circ} \mathrm{C}\right) \text {, } \\
\text { and } \\
\text { extension }(2 \\
\left.\text { min at } 60^{\circ} \mathrm{C}\right) .\end{array}$ & $\begin{array}{c}\text { 5'GGGGGCCTGCTCACGGCGG3' } \\
\text { and } \\
\text { 5'ATTGCAAAAAGTACAGTGAACA3 }\end{array}$ & $\begin{array}{l}\text { Regnery } \\
\text { et al., } \\
\text { (1991) }\end{array}$ \\
\hline Anaplasmataceae & $16 \mathrm{~S}$ & 345 & $\begin{array}{c}40 \text { cycles of } \\
\text { denaturation } \\
\left(20 \mathrm{~s} \text { at } 94^{\circ} \mathrm{C}\right) \text {, } \\
\text { annealing } \\
\left(30 \mathrm{~s} \text { at } 55^{\circ} \mathrm{C}\right) \text {, } \\
\text { and } \\
\text { extension }(5 \\
\left.\text { min at } 72^{\circ} \mathrm{C}\right) \text {. }\end{array}$ & $\begin{array}{c}\text { 5'GGTACCYACAGAAGAAGTCC3' } \\
\text { and 5'TAGCACTCATCGTTT ACA } \\
\text { GC3' }\end{array}$ & $\begin{array}{l}\text { Martin et } \\
\text { al., (2005) }\end{array}$ \\
\hline
\end{tabular}




\section{RESULTS AND DISCUSSION}

Six $P$. picazuro specimens were collected, three of them were parasitized by $O$. erythrocephala (Diptera: Hippoboscidae) (Figure 1), one by C. passerinae (Phthiraptera: Philopteridae) (Figure 2), one by both species of parasites, and one negative for infestation. All ectoparasites were female.

a

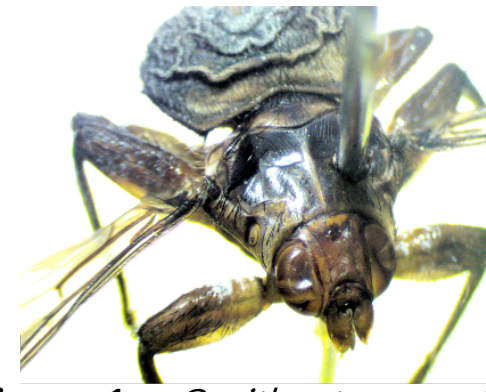

b

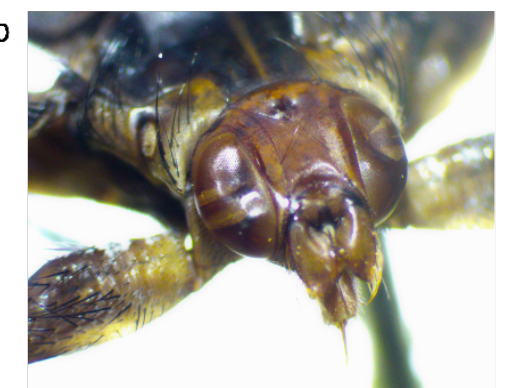

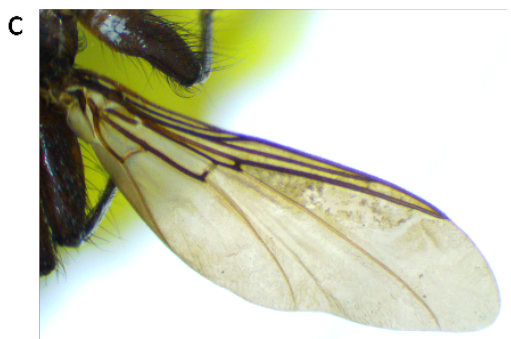

Figure 1 - Ornithoctona erythrocephala collected in Viçosa, Minas Gerais. a) Dorsal view, b) details of head, antenna and foliate palp, c) details of wings.

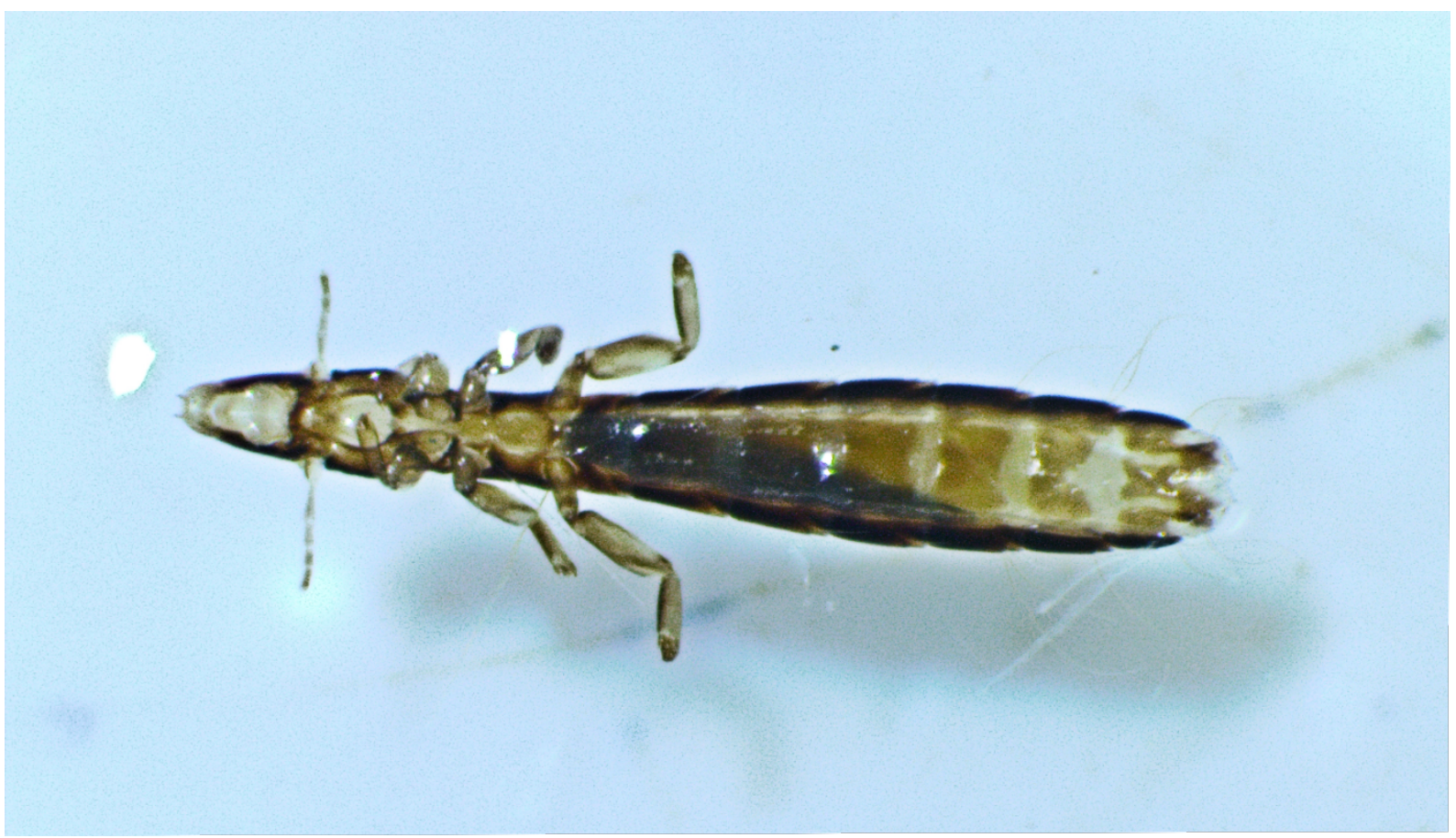

Figure 2 - Ventral view of the Columbicola passerinae collected in Viçosa, Minas Gerais.

The frequency and mean intensity of infestation were respectively, 66\% and 1 for O. erythrocephala, and $33 \%$ and 1 for C. passerinae. Although the knowledge on the parasitological indicators of these Hippoboscidae and Philopteridae species are limited, the values found for the fly corroborate with other studies, since Hippoboscidae collected on different bird species have demonstrated prevalence rates ranging from $1.0 \%$ (Tella et al., 2000) to $85.89 \%$ (Tella et al., 1998). In addition, according to Tossas (2001), low 
parasitism due to the small amount of $O$. erythrocephala per dove does not bring threats to bird health. Studies regarding the prevalence of $C$. passerinae on pigeons found values between 50\% (Valim et al., 2004) and 84.4\%, and mean intensity of 12.2 (Coimbra et al., 2012), which is higher than those found in the present study. This variation may happen because lice infestation is more influenced by host body conditions than by environmental conditions (Clayton et al., 1992).

Maa (1969) reported 76 genera, 25 families and 14 host orders for 0 . erythrocephala and these records have increased due to its low host specificity. This species occurs in Canada, United States, Mexico, Argentina, Bahamas, Bolivia, Colombia, Costa Rica, Cuba, Ecuador, Grenada, Guadeloupe, Guatemala, Virgin Islands, Jamaica, Nicaragua, Panama, Peru, Puerto Rico, Dominican Republic, São Domingos, São Vicente, Uruguay, and Venezuela (Bequaert, 1954).

In Brazil, studies in São Paulo, Mato Grosso, Paraná, Rio Grande do Sul, Santa Catarina, Pernambuco, and Mato Grosso do Sul reported parasitism by this fly on Columbiformes [Zenaida auriculata (Des Murs 1847) and P. picazuro], Galbuliformes [Baryphthengus ruficapillus (Vieillot 1818)], Strigiformes [Tyto furcata (Temminck 1827), Bubo virginianus (Gmelin 1788)], Falconiformes [Milvago chimachima (Vieillot 1816), Micrastur ruficollis (Vieillot 1817), Falco peregrinus (Tunstall 1771), Caracara plancus (Miller 1777), and Milvago chimango (Vieillot 1816)], Accipitriformes [Rupornis magnirostris (Gmelin 1788), Accipiter striatus (Vieillot 1808), Ictinia plumbea (Gmelin 1788), Parabuteo unicinctus (Temminck 1824), and Elanus leucurus (Vieillot 1818)], Cathartiformes [Coragyps atratus (Bechstein 1793)], and Galliformes [Penelope obscura (Temminck 1815) and Crax blumenbachii (Spix 1825)] (Lutz et al., 1915; Bequaert, 1954; Maa, 1969; Graciolli and Carvalho, 2003; Graciolli and Bispo, 2005; Serra-Freire and Quadros, 2013; Lambrecht et al., 2015; Vaz and Teixeira, 2016; Graciolli et al., 2017; Moreira et al., 2019).

The genus Columbicola is worldwide distributed, and its parasitism is restricted to the order Columbiformes. The species $C$. passerinae has been reported in the United States, Mexico, Colombia, Venezuela, Cuba, British West Indies, Virgin Islands, Trinidad, British Guiana, Argentina, Bolivia, and Venezuela (Clayton and Price, 1999). In Brazil, studies performed in São Paulo, Pernambuco, Mato Grosso, and Rio de Janeiro reported the parasitism by this louse on Columbina talpacoti (Temminck 1810) and Columbina minuta (L. 1766) (Roda and Farias, 1999; Oniki, 1999; Valim et al., 2004; Valim, 2019).

Although there are already reports of parasitism by the fly $O$. erythrocephala on $P$. picazuro in Paraná and Pernambuco (Serra-Freire and Quadros, 2013), this is the first 
record of the occurrence of this species of Hippoboscidae in the state of Minas Gerais. Additionally, the present study reports for the first time the parasitism by the louse $C$. passerinae on this species of pigeon.

Phoretic relationship between the ectoparasites was not observed in our study. However, the occurrence of both species in these birds shows the need for further investigations on the interactions they may present, since lice of different families usually fix their jaws in flies of the family Hippoboscidae in order to find new hosts (Keirans, 1975).

The results of the PCR analysis of this study were negative for the pathogens screened; however, Foley et al. (2016) have reported the occurrence of Anaplasma spp. in Hippoboscidae. These findings made the authors question whether these flies would act as biological vectors or simply acquired the bacteria by feeding on diseased animals, acting as mechanical carriers. In our study a small number of specimens were tested; therefore, further studies need to be performed in order to identify the role that these ectoparasites have on the transmission of pathogens and whether they act as biological or mechanical vectors.

\section{CONCLUSION}

Further studies need to be performed in order to identify the role these ectoparasites have on the transmission of pathogens, and whether they act as biological or mechanical vectors, since in this study few samples were tested. To the most of our knowledge, this is the first report of Ornithoctona erythrocephala in the state of Minas Gerais, Brazil and, the first record of parasitism by Columbicola passerinae in Patagioneas picazuro.

Ethics approval: All the international, national, and institutional guidelines for ethical use of animals were followed in this study. The capture of animals used in this study was authorized by the Biodiversity Information and Authorization System (SISBIO) of the Brazilian Institute of Environment and Renewable Natural Resources (IBAMA) under the license number: 13066-2.

\section{Acknowledgments}

The authors are grateful to thank Marcos Antônio Bezerra Santos for his suggestions and support on the development of this study, and CAPES, CNPq and Fapemig by the support to this work.

Archives of Veterinary Science, v.26, n.1, p. 92-103, 2021. 


\section{REFERENCES}

ADRIANO, E.A.; THYSSEN, P.J; CORDEIRO, N.S. Eimeria curvata n. sp. (Apicomplexa: Eimeriidae) in Columbina talpacoti and Columbina squammata (Aves: Columbidae) from Brazil. Memórias do Instituto Oswaldo Cruz, v.95, p.53-55, 2000.

BAKER, J.R. A review of the role played by the Hippoboscidae (Diptera) as vectors of endoparasites. Journal of Parasitology, v.53, p.412-418, 1967.

BEQUAERT, J. A monograph of the Melophaginae, or kedflies, of sheep, goats, deer and andantelopes (Diptera, Hippoboscidae). Entomologica Americana, v.22, p.173-220, 1942.

BEQUAERT, J. The Hippoboscidae or Louse-flies (Diptera) of mammals and birds Part II. Taxonomy, Evolution and Revision of American genera and species. Entomologica Americana, v.34, p.1-232, 1954.

BEQUAERT, J. The Hippoboscidae or Louse-flies (Diptera) of mammals and birds Part II. Taxonomy, Evolution and Revision of American genera and species. Entomologica Americana, v.36, p.417-610, 1957.

CLAYTON, D.H.; GREGORY, R.D.; PRICE, R.D. Comparative ecology of Neotropical lice (Insecta: Phthiraptera). Journal of Animal Ecology, v.61, p.781-795, 1992.

CLAYTON, D.H.; PRICE, R.D. Taxonomy of New World Columbicola (Phthiraptera: Philopteridae) from the Columbiformes (Aves), with descriptions of five new species. Annals of the Entomological Society of America, v.92, p.675-685, 1999.

COHEN, S.; GREENWOOD, M.T.; FOWLER, J.A. The louse Trinoton anserinum (Amblycera: Phthiraptera), an intermediate host of Sarconema eurycerca (Filarioidea: Nematoda), a heartworm of swans. Medical and Veterinary Entomology, v. 5, p. 101-110, 1991.

COIMBRA, M.A.A.; MASCARENHAS, C.S.; MÜLLER, G. et al. Phthiraptera and Gamasida parasites of Columbina picui (Temminck) (Columbiformes: Columbidae) in the State of Rio Grande do Sul, Southern Brazil. Brazilian Journal of Biology, v.72, p.583-585, 2012.

EMERSON, K.C.; PRICE, R.D. A host-parasite list of the Mallophaga on mammals. Miscellaneous publications of the Entomological Society of America, v.12, p.1-72, 1981. 
FOLEY, J.E.; HASTY, J.M.; LANE, R.S. Diversity of rickettsial pathogens in Columbian blacktailed deer and their associated keds (Diptera: Hippoboscidae) and ticks (Acari: Ixodidae). Journal of Vector Ecology, v.41, p.41-47, 2016.

GONZALEZ, D.; DAUGSCHIES, A.; RUBILAR, L. et al. Fauna parasitaria de la Tórtola común (Zenaida auriculata de Murs, 1847) Columbiformes: Columbidae) em Nuble, Chile. Parasitología Latinoamericana, 59, 37-41, 2004.

GRACIOLLI, G.; BISPO, A.A. Hippoboscidae (Diptera) ectoparasitos sobre seis espécies de corujas (Strigiformes) no estado do Paraná, Sul do Brasil. Brazilian Journal of Ornithology, v.13, p.181-182, 2005.

GRACIOLLI, G.; CARVALHO, C.J.B. Hippoboscidae (Diptera: Hippoboscoidea) no Estado do Paraná, Brasil: chaves de identificação, hospedeiros e distribuição geográfica. Revista Brasileira de Zoologia, v.20, p.667-674, 2003.

GRACIOLLI, G.; CARVALHO, L.F.A.C.; ERIKSSON, A.F. et al. Lista das espécies de Hippoboscoidea (Diptera) no estado de Mato Grosso do Sul, Brasil. Iheringia Serie Zoologica. 107(supl.):e2017137, 2017.

GUIMARÃES, L.R. Sobre alguns ectoparasitos de aves e mamíferos do litoral paranaense. Arquivos do Museu Paranaense, v.4, p.179-190, 1945.

HILDEBRANDT, A., FRANKEB, J., MEIERA, F. et al. The potential role of migratory birds in transmission cycles of Babesia spp., Anaplasma phagocytophilum, and Rickettsia spp. Ticks and Tick-Borne Diseases, v.1, p.105-107, 2010.

JOHNSON, J.P; CLAYTON, D.H. Biology, ecology and evolution of chewing lice. In: PRICE, R.D.; HELLENTHAL, R.A.; PALMA, R.L.; JOHNSON, K.P.; CLAYTON, D.H.; Chewing lice: World checklist and biological overview. Illinois Natural History Survey, Springfield, Illinois, USA, 2003, p.449-476.

KEIRANS, J.E. A review of the phoretic relationship between Mallophaga (Phthiraptera: Insecta) and Hippoboscidae (Diptera: Insecta). Journal of Medical Entomology, v.12, p.71-76, 1975.

LAMBRECHT, F.M.; SERRA-FREIRE, N.M.; FARIAS, N.A.R. Milvago chimango (Vieillot, 1816) (Aves: Falconidae) novo hospedeiro para Ornithoctona erythrocephala (Leach, 1817) 
(Diptera: Hippoboscidae) no município do Rio Grande, Rio Grande do Sul, Brasil. Revista UNIABEU, v.8, p.257-261, 2015.

LEFEBERVE, L. Stability flock composition in urbans pigeons. The Auk, v.2, p.886-888, 1985.

LUTZ, A.; NEIVA, A.; COSTA-LIMA, A. Sobre "Pupipara" ou "Hippoboscidae" de aves brasileiras. Memórias do Instituto Oswaldo Cruz, v.7, p.1-29, 1915.

MAA, T.C. A revised checklist and concise host index of Hippoboscidae (Diptera). Pacific Insects Monographics, v.20, p.261-299, 1969.

MAA, T.C. Family Hippoboscidae. In: EVENHUIS, N.L Catalog of the Diptera of the Australasian and Oceanian regions. Bishop Museum Press \& EJ Brill, 1989, p.785-789.

MAA, T.C.; PETERSON, B.V. Hippoboscidae. In: MCALPINE, B.V., PETERSON, B.V., SHEWELL, G.E. et al. Manual of Neartic Diptera, 2. Research Branch Agriculture Canada, Ottawa, 1987, 1332p.

MARTIN, A.R.; BROWN, G.K.; DUNSTAN, R.H. et al. Anaplasma platys an improved PCR for its detection in dogs. Experimental Parasitolology, v.109, p.176-180, 2005.

MCCLURE, H.E. 1984. The occurrence of hippoboscid flies on some species of birds in southern California. Journal of Field Ornithology, v.55, p.230-240, 1984.

MOREIRA, R.F.; FARENZI, L.C.; SOUZA, U.A. et al. Pupipara (Diptera, Hippoboscidae) in wild birds attended at a rehabilitation center in southern Brazil. Revista Brasileira de Parasitologia Veterinária, v.28, p.330-332, 2019.

ONIKI, Y. Avian parasites and notes on habits of lice from Mato Grosso, Brazil. Iheringia Serie Zoologica, v.86, p.183-190, 1999.

PAVLOVSKY, E.N.; TOKAREVICH, K.N. 1966. Birds and inflectional pathology of men. Medicine Publ., Leningrad.

PRICE, R.D.; HELLENTHAL, R.A.; PALMA, R.L. World checklist of chewing lice with host associations and keys to families and genera. In: PRICE, R.D.; HELLENTHAL, R.A.; PALMA, R.L. The chewing lice: world checklist and biological overview. Johnson, K.P. and Clayton, D.H. Illinois, Natural History Survey Special Publication, 2003, p.1-448. 
RAMOS, R.A.N.; CAMPBELL, B.E.; WHITTLE, A. et al. Occurrence of Ixodiphagus hookeri (Hymenoptera: Encyrtidae) in Ixodes ricinus (Acari: Ixodidae) in Southern Italy. Ticks and Tick-Borne Diseases, v.6, p.234-236, 2015.

RANVAUD, R.; BUCHER, E.H. Eared doves outbreak in the South America: Patterns and characteristcs. Acta Zoologica Sinica, v.52, p.564-567, 2006.

REGNERY, R.L.; SPRUILL, C.L.; PLIKAYTIS, B.D. Genotypic identification of rickettsiae and estimation of interspecies sequence divergence for portions of two rickettsial genes. Journal of Bacteriology, v.173, p.1576-1589, 1991.

RODA, A.S.; FARIAS, A.M.I. Aves silvestres infestadas por Phthiraptera (Insecta) na Zona da Mata Norte de Pernambuco, Brasil. Revista Brasileira de Zoologia, v.16, p.871-878, 1999.

SEEGAR, W.; SCHILLER, E.; SLADEN, W.; TRPIS, M. A mallophaga, Trinoton anserinum, as a cyclodevelopmental vector for a heartworm parasite of waterfowl. Science, v. 194, n. 4266, p. 739-741, 1976.

SERRA-FREIRE, N.M.; QUADROS, R.M. Relação trófica entre Ornithoctona erythrocephala (Leach, 1817), Falculifer caraibensis Gaud \& Barré, 1992, e Pagiogenas picazuro (Temminck, 1813). Revista UNIABEU, v.6, p.348-354, 2013.

TELLA, J.L.; GAJÓN, A.; GORTÁZAR, C. et al. High host specificity of Crataerina melbae (Diptera: Hippoboscidae) in a mixed colony of birds. Journal of Parasitology, v.84, p.198200, 1998.

TELLA, J.L.; RODRÍGUEZ-ESTRELLA, R.; BLANCO, G. Louse flies on birds of Baja California. Journal of Wildlife Diseases, v.36, p.154-156, 2000.

TOSSAS, A.G. Two new avian host records for Ornithoctona erythrocephala (Diptera: Hippoboscidae) in Puerto Rico. Caribbean Journal of Science, v.37, p.115-116, 2001.

VALIM, M.P. 2019. Philopteridae in Catálogo Taxonômico da Fauna do Brasil. PNUD. http://fauna.jbrj.gov.br/fauna/faunadobrasil/91515 Accessed 21 July 2019.

VALIM, M.P., SERRA-FREIRE, R.T., FONSECA, M.A. et al. Níveis de Enzootia por ectoparasitos em amostras de rolinha [Columbina talpacoti (Temminck, 1810)] no Rio de Janeiro, Brasil. Entomología y Vectores, v.11, p.589-598, 2004. 
VAZ, F.F.; TEIXEIRA, V.N. New records of three hippoboscid species on newly captured birds from nature in Paraná, Brazil. Revista Brasileira de Parasitologia Veterinária, v.25, p.501-503, 2016.

WIKIAVES. 2008. WikiAves, a Enciclopédia das Aves do Brasil. http://www.wikiaves.com.br Accessed 21 October 2019. 